\title{
Citrus tristeza Virus Variants and their Distribution in Mandarin Orchards in Northeastern Himalayan Hill Region of India
}

\author{
S. Palchoudhury ${ }^{1,2}$, P. Ghimiray ${ }^{1}$, M.K. Biswas ${ }^{2}$ and K.K. Biswas ${ }^{1}$ * \\ ${ }^{1}$ Advanced Centre for Plant Virology, Division of Plant Pathology, ICAR-Indian Agricultural \\ Research Institute, New Delhi, India \\ ${ }^{2}$ Department of Plant Protection, Palli Siksha Bhavana, Visva-Bharati University, \\ West Bengal, India \\ *Corresponding author
}

\section{A B S T R A C T}

Northeastern Himalayan hill region of India is known to produce quality mandarin $(C$. reticulata) commercially. Citrus tristeza virus (CTV), an aphid (Toxoptera citricidus) transmitted closterovirus, is a major problem to cause decline of mandarin in this region. The different orchards of Mirik in the Darjeeling and Rumtek of East Sikkim were surveyed. CTV incidence of 48-53.3\% in Mirik and 40-60\% in Rumtek were estimated using direct antigen coated-ELISA and polymerase chain reaction. Nine CTV isolates; 6 from Mirik and 3 from Rumtek were characterized based on sequencing of 5'ORF1a gene fragments (404nt) and CP gene (672nt). The present isolates shared $85-100 \%$ nt identity and formed 3 genogroups for 5' ORF1a; and 91-100\% nt identity and formed 4 genogroups for CP gene, among them. Majorities of the present isolates are related with decline inducing Indian isolate $\mathrm{Kpg} 3$ indicating decline inducing $\mathrm{CTV}$ isolates are common in this region. CTV isolates of Sikkim were characterized for the first time and all the Sikkim isolates are genetically related with CTV isolate Kpg3. One new CTV isolate K38 related to the severe Florida isolate T3 was reported from Mirik. The recombinationdetecting program RDP4 identified two CTV isolates K37 and K38 of Mirik as putative recombinants. The previous and the present studies report occurrence of at least five CTV variants in Northeastern Himalayan hill region of India.

\section{Introduction}

Citrus tristeza virus (CTV), a closterovirus is one of the important causal agents causing decline disease in citrus worldwide. Over the last 10 decades CTV has killed or caused unproductive of more than 100 million citrus trees all over the world (Moreno et al., 2008). CTV is a phloem-limited, flexuous filamentous plant virus with particle size of 2000 X $11 \mathrm{~nm}$ and predominantly transmitted by aphid (Toxoptera citricida) in a semipersistent manner (Bar-Joseph et al., 1989).
CTV contains positive sense, ssRNA genome, $\sim 19.3 \mathrm{~kb}$ in length and comprises 12 ORFs (ORF1a-b and ORFs 2-11) potentially encoding at least 19 putative proteins and two UTRs (Karasev et al., 1995).

The ORFs $1 \mathrm{a}$ and $1 \mathrm{~b}$ encode replication related proteins translated from genomic RNA, whereas the ten, ORFs 2-11 3' proximal encoded proteins p33, p6, p65, p61, p27, p25 (ORF7), p18, p13, p20 and p23 are expressed 
via 3' co-terminal sub genomic RNA (sgRNA) (Satyanarayana, 2000). Citrus are cultivated in diverse ecological conditions and affected by several CTV variants/strains resulting in production of diverse disease syndromes (Bar Joseph and Dawson, 2008; Moreno et al., 2008). Extensive genetic diversity in CTV in citrus growing regions of the world including India has been reported time to time (Rubio et al., 2001; Biswas, 2010; Biswas et al., 2012b; Tarafdar et al., 2013). Complete genome analysis identified seven distinct CTV genotypes internationally and they are VT, T36, T30, T3, B165, HA165 and RB (resistance breaking) (Roy and Brlansky, 2010; Melzer et al., 2010; Biswas et al., 2012a; Harper, 2013). Genetic recombination is a major phenomenon in the evolution of CTV variants (Martin et al., 2009; Biswas et al., 2012a, 2012b; Tarafdar et al., 2013).

Citrus is cultivated almost in all the geographical zones (Northeast, South, Northwest and Central) of India. CTV is present wherever the citrus is grown naturally or commercially in India (Ahlawat, 1997; Biswas, 2008; Biswas et al., 2014). CTV causes leaf yellowing, growth cessation, chlorosis, plant stunting with poor fruit yield and quality, and ultimately tree decline in India (Chakroborty et al., 1992; Biswas, 2008; Sharma et al., 2011; Singh et al., 2013; Biswas et al., 2014). Northeastern Himalayan region of India is known to produce mandarin, called Darjeeling mandarin $(C$. reticulata) commercially. CTV is a major problem in the Darjeeling hills causing decline of mandarin orchards which are being wiping out (Biswas, 2008; Biswas et al., 2012a; Tarafdar et al., 2013, Biswas et al., 2014). Occurrence of CTV in mandarin orchards in Sikkim State has also been reported earlier (Kishore et al., 2010) but till to date, no CTV isolates from this State has been characterized genetically. Several CTV isolates of the Darjeeling hills have been genetically characterized and occurrence of 45 CTV variants in this hill regions are reported (Biswas et al., 2012b). Earlier, one CTV isolate which is VT type has been characterized genetically but using more number of isolates, the genetic diversity of CTV in Mirik, the important quality mandarin growing area of the Darjeeling hills was not yet studied. Therefore, in present study, an effort has been made to determine the genetic diversity of CTV and distribution of its variants in Mirik and Sikkim hills in Northeastern Himalayan region of India.

\section{Materials and Methods}

\section{Survey of citrus orchards, CTV incidence and diagnosis}

The Darjeeling mandarin (Citrus reticulata) orchards of Mirik area in Darjeeling and Rumtek area of East Sikkim hills were surveyed during the year 2015-2016 to study incidence of CTV. Equal number of three orchards from Mirik bustey and Murmah of Mirik, and one orchard each from four locations of Sajong, Rawtey, Lower Sajong and Orange village of Rumtek were surveyed. Twigs of about 10-25 mandarin trees showing apparent disease symptoms from each orchard were collected and brought to laboratory for molecular assays. To detect CTV in the infected samples, direct antigen coated enzyme linked immuno-sorbent assay (DACELISA) developed earlier (Clark and BarJoseph, 1984) and used to detect CTV in infected citrus plant in India previously (Biswas, 2008; Tarafdar et al., 2013) was followed.

Reverse transcriptase-PCR, cloning and sequencing of genomic regions of $\mathrm{CTV}$ isolates

Six CTV isolates designated as K37 to K42 from six orchards of Mirik and three 
designated as RS4, RR5 and RL1 from three orchards of Rumtek were taken for molecular characterization based on sequencing of 404 nt fragment of ORF1a (L ProI domain) (5'ORF1a) and complete CP (ORF7, 672nt) genes. Total plant RNA was isolated from tender bark tissues using $\mathrm{SV}$ total RNA isolation system (Promega, Madison, USA). The first strand cDNA was synthesized using M-MLV-Reverse transcriptase (Promega, Madison, USA) following the method used earlier (Biswas, 2010). The 5'ORF1a fragment and CP gene of the present CTV isolates were amplified by polymerase chain reaction (PCR) using protocol and primers used previously (Biswas, 2010). The amplicons were purified using QIAquick PCR Purification Kit (Qiagen, Maryland), cloned into the T\&A cloning vector system (RBC, $\mathrm{UK}$ ) and grown in $E$. coli strain DH5 $\alpha$ using standard method. The clones of viral DNA were sequenced by vector derived M13 forward and M13 reverse primers in an automatic sequencer (ABI 3011, Chromous Biotech Pvt. Ltd., Bangalore, India). Two clones of each isolate were sequenced and consensus sequences were taken for further analysis. Sequences of two independent clones of each genomic fragment shared an identity of more than $99.5 \%$ among them, which indicated that they were amplified from same genotype.

\section{Sequence analysis}

The corresponding sequences of CTV isolates, VT (U56902), T36 (U16304), T30 (AF260651), T3 (KC525952), B165 (EU076703), HA16-5 (GQ454870), and NZRB-G90 (FJ525432) representing the seven recognized CTV genotypes identified worldwide (Melzer et al., 2010; Biswas et al., 2012a; Harper, 2013) were used for sequence comparison. Further, previously reported 13 CTV variants, Mnp1, Mnp2, Mnp3, Kpg3, K5, D13, BAN-1, AG-26, AR-1, Kpg2, K10,
AG-28 and BAN-2 for 5'ORF1a and 9 CTV variants, Mnp1, Mnp2, Mnp3, Kpg3, K5, Kpg2, P14, K27 and TP6 for CP gene from India (Biswas et al., 2012b; Tarafder et al., 2013; Palchoudhury et al., 2015) were used. The multiple sequence alignments were carried out using the program Clustal W, version 1.6 (Thomson et al 1997). Nehibourjoining phylogenetic tree were constructed using maximum likelihood parameter of MEGA 6.0 (Tamura et al., 2015). Sequence identity matrix was generated using Sequence Demarcation Tool (SDT) version 1.2 (Muhire et al., 2014).

The putative recombination events were identified using recombination detection program (RDP4) version 4.55 implementing seven algorithms, RDP, GeneConv, Bootscan, MaxChi, Chimera, SiScan and 3SEQ (Martin et al., 2015) using default parameter values for the different detection programs. When the same recombination events were detected by more than two algorithms, they were considered as evidence of putative recombination.

\section{Results and Discussion}

\section{Detection of CTV and estimation of disease incidence}

Six mandarin orchards two locations in Mirik areas of the Darjeeling and four orchards in four locations of Rumtek areas of East Sikkim were surveyed. The plant showing poor growth along with leaf chlorosis and decline symptoms were considered, and twigs from those plants were collected and brought to laboratory. CTV infection was detected by DAC-ELISA. About $40-60 \%$ of samples tested showed positive ELISA reaction (Table. 1). The virus titre in the infected samples was measured using optical density (OD) values at $405 \mathrm{~nm}$ in ELISA reader. In ELISA reader, the overall OD values of 3-4 
folds compared to healthy control were calculated (Table. 1). Randomly, 6 samples from the Mirik and three samples of Rumtek areas showing positive ELISA reaction were subjected to PCR using specific primer targeting CP gene of CTV genome. All the citrus samples were found to be PCR positive. Randomly the three samples of Orange village showing no result in DAC-ELISA were tested through PCR similarly, but these samples were PCR negative. Based on ELISA results, CTV incidence of $48.0-53.3 \%$ in Mirik and 40-60\% in Rumtek were estimated (Table 1). Interestingly, one orchard in Orange village of Rumtek areas surveyed was found to be disease free as no samples showed positive ELISA reaction (Table 1).

\section{Cloning of gene sequence of CTV isolates}

The CP genes and 5'ORF1a fragments (L ProI domain) of six CTV isolates, designated as $\mathrm{K} 37, \mathrm{~K} 38$, K39, K40, K41 and K42 of the Mirik and three designated as RS4, RR5 and RL1 of Rumtek were amplified by specific primer pairs and the amplicons were purified, cloned, analyzed and compared with other isolate (Table. 2 and Fig.1). The nucleotide sequences of all the present CTV isolates were deposited in NCBI GenBank (Table 2).

\section{Sequence analysis and genetic variation in CTV isolates}

Pair wise sequence analysis for 5' ORF1a showed that the present CTV isolates shared $85-100 \%$ nt identities among them. Similar of $80-100 \%$ nt identities were found among Indian and among all the CTV isolates (Fig. $2 a)$. In the phylogenetic analysis, the present isolates were segregated into three genogroups (Fig. 3a). The CTV isolates K37, K40, K39, K41, RL1, RS4 and RR5 all were found to be similar showing by $97-100 \% \mathrm{nt}$ identities to each other, and grouped together along with previously reported decline inducing Indian CTV isolate Kpg3 and Israel severe isolate VT (Table 2). The isolate K38 grouped with Florida severe isolate T3. The isolate K42 grouped with previously reported Indian isolate K10 and B165.

For the CP genes, the pair wise sequence analysis showed that the present isolates shared 91-100\% nt identity among them. Among the Indian and among all the CTV isolates a similar of $90-100 \%$ nt identity were found (Fig.2b). In the phylogenetic analysis, the present isolates formed four genogroups (Fig.3b). The isolate K40 and K39 were similar $(96 \%)$ to each other and grouped with previously reported Indian isolates $\mathrm{K} 27$ and B165, and Israel severe isolate VT (Table 2). Isolate K42 grouped with previously reported Indian isolate Kpg2 and resistance breaking New Zealand isolate RB-G90. The isolate K37 and K38 was similar (100\%) to each other and placed in the same group along with previously reported Indian isolate K10 and Florida isolate T3. Four present isolates K41, RS4, RR5 and RL1 were similar (99-100\%) to each other and grouped with previously reported decline inducing Indian isolate $\mathrm{Kpg} 3$ and Hawaii isolate HA16-5.

\section{Discordance in phylogenetic relationships for different genomic regions of CTV isolates}

In closer inspection, it was found that the genogroups formed based on 5'ORF1a and $\mathrm{CP}$ gene were discordant. For instance, the isolate $\mathrm{K} 37$ placed in the group with isolate VT for 5'ORF1a but it placed in the group with isolate $\mathrm{T} 3$ for $\mathrm{CP}$ gene. In another case, the isolate $\mathrm{K} 42$ grouped with B165 for 5'ORF1a but grouped with RB-G90 for CP gene. The evidence of discordance in phylogenetic relationships for 5'ORF1a and $\mathrm{CP}$ genes in the present study agreed the previously reported discordance in phylogenetic relationships for different 
genomic regions of CTV (Rubio et al., 2001; Sharma et al., 2011; Biswas et al., 2012a, 2012b; Palchoudhury et al., 2015).

\section{Recombination in CTV isolates}

When nine present CTV isolates were tested, recombination-deticting program, RDP4 detected recombination events only in two present CTV isolates isolate $\mathrm{K} 37$ and $\mathrm{K} 38$. Isolate K38 showed recombination in both the 5'ORF1a and CP gene and isolate K37 only in for $\mathrm{CP}$ gene. Isolates K38 showed recombination event at the position from 17 to $134 \mathrm{nt}$ in 5'ORF1a fragment supported by maximum probability $\left(\mathrm{p}=5.865 \times 10^{-1}\right)$, involving the previously reported Indian isolates $\mathrm{Kpg} 3$ and $\mathrm{AG} 26$ as major and $\mathrm{Kpg} 2$ and AR-1 as minor donors (Table. 3). The isolates $\mathrm{K} 37$ and $\mathrm{K} 38$ showed a similar recombination event at the position from 419 to $625 \mathrm{nt}$ in $\mathrm{CP}$ gene supported by maximum probability $\left(\mathrm{p}=5.943 \times 10^{-1}\right)$, involving the previously reported $\mathrm{Kpg} 3$ and $\mathrm{Kpg} 2$ as major and TP6 as minor donors (Table.3). Interestingly all the present major donors are CTV isolates of Northeastern India. Thus the present study indicated that isolate K38 is strong recombinant as it shows recombination in both the genomic regions, ORF1a fragment and $\mathrm{CP}$ gene.

CTV causes a general decline symptom along with chlorosis, poor and stunted growth of the mandarin tree in the majority of the orchards in the Darjeeling hills (Biswas et al., 2014). CTV incidence as high as $48.2 \%$ in the Darjeeling hills (Biswas, 2008; Biswas et al., 2014) and $46.2 \%$ in Sikkim hills (Kishore et al., 2010) has been reported earlier. The data in the present study revealed that CTV incidence is $48-53.3 \%$ in the Darjeeling hills and $40-60 \%$ in Sikkim hills. Thus, the previous (Biswas, 2008; Biswas et al., 2014; Kishore et al., 2010) and the present studies show that incidence of CTV is very high in
Northeastern Himalayan region of India. In these regions, prevalence of aphid vector ( $T$. citricida) is very much common (Biswas et al., 2008, Tarafdar et al., 2013). Vertical transmission through insects, horizontal spread through infected planting material, and perennial nature of citrus trees exposing multiple CTV infection are the potential causes for higher incidence of CTV in Northeastern regions of India.

Genetic recombination is a major phenomenon in the evolution of CTV variants (Martin et al., 2009; Biswas et al., 2012a, 2012b; Tarafdar et al., 2013). Evidence for recombination events in the origin of many divergent CTV isolates has been documented earlier in India (Sharma et al., 2011, Biswas et al., 2012 a, b; Singh et al., 2013). The present study determined that isolates 37 and K38 are recombinant isolates. Therefore, discordant phylogenetic relationships were observed between them, as K37 and K38 grouped with T3 for CP gene whereas, isolate K37 grouped with VT and isolate K38 with T3 for ORF1a. Due to recombination phenomenon, these two isolates are similar in nucleotide identity (100\% nt identity) for CP gene but different from each other by $91 \% \mathrm{nt}$ identity for 5'ORF1a. It is also shown that sequence analysis of one genomic region of CTV could not be differentiating the CTV isolates.

CTV isolates in mandarin growing areas of Sikkim was characterized genetically for the first time based on 5'ORF1a and CP gene. They are genetically related to CTV isolate $\mathrm{Kpg} 3$, the mandarin decline inducing isolate of the Darjeeling hills. Earlier, only one isolate K27 of Mirik was genetically characterized and identified as VT genotype (Biswas et al., 2012b). In present study, analyzing six isolates from Mandarin growing areas of Mirik determined occurrence of at least 3-4 genotypes and majorities are of 
Kpg3/VT genotypes, indicating prevalence of decline inducing CTV isolates are common in this hill regions.

The present study determined occurrence of several variants of CTV in Northeastern Himalayan hill region in India. Earlier, 26 CTV isolates of the Darjeeling hills were collected during the year of 2007-2008 and analysed based on 5' ORF1a and CP gene; and it has been reported that 4-5 CTV variants exist in this citrus growing region (Biswas et al.,2012b). In the present when 9 CTV isolates of Mirik and Rumtek were included and overall analyses shows occurrence of at least five variants, Kpg3/VT type, K10/B165 type, Kpg2/T30 type, K5 (distinct) and K38/T3 type in the Darjeeling hills and its surrounding areas. Earlier CTV genotype T3 has not been reported from the Darjeeling hills. The present study additionally identified one Mirik CTV isolate K38 to a T3 genotype. Recently, Palchoudhury et al. (2015) characterized some CTV isolates of citrus growing regions of Manipur and reported occurrence of VT/Kpg3 and T3 genotypes in this state.

Table.1 Disease incidence of Citrus tristeza virus in Northeastern Himalayan hill region of India

\begin{tabular}{|c|c|c|c|c|c|c|}
\hline District & Area & Location & $\begin{array}{l}\text { No. pl } \\
\text { infected/No. } \\
\text { pl tested (\% } \\
\text { pl infection) }\end{array}$ & $\begin{array}{l}\text { OD value } \\
\text { at } 405 \\
\text { (x fold) }\end{array}$ & Symptoms & $\begin{array}{l}\text { PCR } \\
\text { confirmation }\end{array}$ \\
\hline \multirow[t]{6}{*}{ Darjeeling } & Mirik & $\begin{array}{l}\text { Mirik } \\
\text { bustey }\end{array}$ & $8 / 15(53.33 \%)$ & $1.09(\sim 3)$ & Chl, Pg & $+\mathrm{ve}$ \\
\hline & & $\begin{array}{l}\text { Mirik } \\
\text { bustey }\end{array}$ & & $1.15(\sim 3)$ & Chl & + ve \\
\hline & & $\begin{array}{l}\text { Mirik } \\
\text { bustey }\end{array}$ & & $1.35(\sim 3)$ & $\mathrm{Pg}, \mathrm{St}$ & $+\mathrm{ve}$ \\
\hline & & Murmah & $\begin{array}{l}12 / 25 \\
(48.00 \%)\end{array}$ & $1.23(\sim 3)$ & Chl, Pg & $+v e$ \\
\hline & & Murmah & & $1.17(\sim 3)$ & Chl, Pg & $+\mathrm{ve}$ \\
\hline & & Murmah & & $1.81(\sim 4)$ & Chl, Pg, St & $+\mathrm{ve}$ \\
\hline \multirow[t]{4}{*}{ East Sikkim } & Rumtek & Sajong & $6 / 15(40 \%)$ & $1.18(\sim 3)$ & Chl, Pg & +ve \\
\hline & & Rawtey & $12 / 20(60 \%)$ & $1.27(\sim 3)$ & $\mathrm{Chl}, \mathrm{Pg}, \mathrm{St}$ & $+\mathrm{ve}$ \\
\hline & & $\begin{array}{l}\text { Lower } \\
\text { Sajong }\end{array}$ & $4 / 10(40 \%)$ & $1.02(\sim 3)$ & Chl, Pg & +ve \\
\hline & & $\begin{array}{l}\text { Orange } \\
\text { village } \\
\text { orchards } \\
\end{array}$ & $0 / 15(0 \%)$ & $0.80(\sim 2)$ & Chl & -ve \\
\hline
\end{tabular}

OD values of positive, healthy and buffer control are 1.89, 0.42 and 0.29 , respectively; $x$ fold titer values of infected samples were calculated compared with the OD values of healthy control; Chl=Chlorosis, $\mathrm{Pg}=\mathrm{Poor}$ growth, $\mathrm{St}=$ Stunting 
Table.2 Molecular characterization of Citrus tristeza virus isolates of Northeastern Himalayan hill region of India

\begin{tabular}{|c|c|c|c|c|c|c|c|c|}
\hline \multirow[t]{2}{*}{ SN } & \multirow{2}{*}{$\begin{array}{l}\text { CTV } \\
\text { Isolate }\end{array}$} & \multirow{2}{*}{$\begin{array}{c}\text { Location } \\
\text { of CTV samples }\end{array}$} & \multirow[t]{2}{*}{ Host } & \multirow{2}{*}{$\begin{array}{c}\text { Symptom } \\
\text { S }\end{array}$} & \multirow{2}{*}{$\begin{array}{c}\text { Group } \\
\text { for 5' } \\
\text { ORF1a }\end{array}$} & \multirow{2}{*}{$\begin{array}{c}\text { Group } \\
\text { for CP } \\
\text { gene }\end{array}$} & \multicolumn{2}{|c|}{ Accession number } \\
\hline & & & & & & & ORF1a & $\mathbf{C P}$ \\
\hline 1 & K37 & $\begin{array}{c}\text { Mirik bustey, Mirik, } \\
\text { Darjeeling }\end{array}$ & $\begin{array}{l}\text { Darjeeling Mandarin } \\
\text { (C. reticulata) }\end{array}$ & Chl, Pg & $\mathrm{Kpg} 3 / \mathrm{VT}$ & K10/T3 & KY567992 & KY567998 \\
\hline 2 & K38 & $\begin{array}{c}\text { Mirik bustey, Mirik, } \\
\text { Darjeeling }\end{array}$ & $\begin{array}{l}\text { Darjeeling Mandarin } \\
\text { (C. reticulata) }\end{array}$ & Chl & T3 & K10/T3 & KY567993 & KY567999 \\
\hline 3 & K39 & $\begin{array}{c}\text { Mirik bustey, Mirik, } \\
\text { Darjeeling }\end{array}$ & $\begin{array}{l}\text { Darjeeling Mandarin } \\
\text { (C. reticulata) }\end{array}$ & $\mathrm{Pg}, \mathrm{St}$ & $\mathrm{Kpg} 3 / \mathrm{VT}$ & $\mathrm{B} 165 / \mathrm{VT}$ & KY567994 & KY568000 \\
\hline 4 & K40 & $\begin{array}{l}\text { Murmah, Mirik, } \\
\text { Darjeeling }\end{array}$ & $\begin{array}{l}\text { Darjeeling Mandarin } \\
\text { (C. reticulata) }\end{array}$ & Chl & $\mathrm{Kpg} 3 / \mathrm{VT}$ & $\mathrm{B} 165 / \mathrm{VT}$ & KY567995 & KY568001 \\
\hline 5 & K41 & $\begin{array}{l}\text { Murmah, Mirik, } \\
\text { Darjeeling }\end{array}$ & $\begin{array}{l}\text { Darjeeling Mandarin } \\
\text { (C. reticulata) }\end{array}$ & Chl, Pg & Kpg3/VT & $\begin{array}{c}\text { Kpg3/ } \\
\text { HA16-5 }\end{array}$ & KY567996 & KY568002 \\
\hline 6 & K42 & $\begin{array}{l}\text { Murmah, Mirik, } \\
\text { Darjeeling }\end{array}$ & $\begin{array}{l}\text { Darjeeling Mandarin } \\
\text { (C. reticulata) }\end{array}$ & Chl, Pg & $\begin{array}{c}\text { K10/B16 } \\
5\end{array}$ & $\begin{array}{c}\text { Kpg2/ } \\
\text { RB-G90 }\end{array}$ & KY567997 & KY568003 \\
\hline 7 & RS4 & $\begin{array}{l}\text { Sajong, Rumtek, East } \\
\text { Sikkim }\end{array}$ & $\begin{array}{l}\text { Darjeeling Mandarin } \\
\text { (C. reticulata) }\end{array}$ & Chl, Pg & $\mathrm{Kpg} 3 / \mathrm{VT}$ & $\begin{array}{c}\text { Kpg3/ } \\
\text { HA16-5 }\end{array}$ & MF078624 & MF078627 \\
\hline 8 & RR5 & $\begin{array}{c}\text { Rautey, Rumtek, East } \\
\text { Sikkim }\end{array}$ & $\begin{array}{l}\text { Darjeeling Mandarin } \\
\text { (C. reticulata) }\end{array}$ & Chl, Pg & $\mathrm{Kpg} 3 / \mathrm{VT}$ & $\begin{array}{c}\text { Kpg3/ } \\
\text { HA16-5 }\end{array}$ & MF078625 & MF078628 \\
\hline 9 & RL1 & $\begin{array}{c}\text { Lower Sajong, Rumtek, } \\
\text { East Sikkim }\end{array}$ & $\begin{array}{l}\text { Darjeeling Mandarin } \\
\text { (C. reticulata) }\end{array}$ & Chl & $\mathrm{Kpg} 3 / \mathrm{VT}$ & $\begin{array}{c}\text { Kpg3/ } \\
\text { HA16-5 }\end{array}$ & MF078626 & MF078629 \\
\hline
\end{tabular}

Chl=Chlorosis, $\mathrm{Pg}=$ Poor growth, $\mathrm{St}=$ Stunting 
Table.3 Recombination events of the present Citrus tristeza virus isolates detected in recombination-detecting program RDP4

\begin{tabular}{|c|c|c|c|c|c|}
\hline $\begin{array}{l}\text { Recombinan } \\
t \text { isolate }\end{array}$ & $\begin{array}{l}\text { Genomi } \\
\text { c region }\end{array}$ & $\begin{array}{l}\text { Recombination } \\
\text { site at the } \\
\text { sequence } \\
\text { position of gene }\end{array}$ & $\begin{array}{l}\text { Donor ( Major } \\
\text { X Minor) } \\
\text { isolate }\end{array}$ & $\begin{array}{l}\text { Algorithm } \\
\text { detected } \\
\text { recombinatio } \\
\text { n event }\end{array}$ & $\begin{array}{l}\text { Maximum P } \\
\text { value }\end{array}$ \\
\hline K38 & ORF1a & $17-134 \mathrm{nt}$ & $\begin{array}{l}\text { Kpg3 x Kpg2, } \\
\text { AG26 x AR-1 }\end{array}$ & $\mathrm{M}, \mathrm{S}, \mathrm{B}$ & $5.865 \times 10^{-1}$ \\
\hline K38 & $\mathrm{CP}$ & $419-625$ & $\begin{array}{l}\text { Kpg2 x TP6, } \\
\text { Kpg3 x Kpg2 }\end{array}$ & $\mathrm{G}, \mathrm{B}, \mathrm{C}, \mathrm{S}$ & $5.943 \times 10^{-1}$ \\
\hline K37 & $\mathrm{CP}$ & $419-625$ & $\begin{array}{l}\text { Kpg2 × TP6, } \\
\text { Kpg3 x Kpg2 }\end{array}$ & $\mathrm{G}, \mathrm{B}, \mathrm{C}, \mathrm{S}$ & $5.943 \times 10^{-1}$ \\
\hline
\end{tabular}

G: Genecov, B: Bootscan, M: Maxchi, C: Chimera, S: Siscan implemented in the recombination-detecting program RDP4. Maximum P value that detected the evidence of recombination event (obtained by any of the algorithms in RDP4); $\mathrm{P}$ value detected evidences of recombination events among the isolates and maximum $\mathrm{P}$ value $>0.05$ was considered to be significant

Fig.1 Polymerase chain reaction of nucleotide sequence of Citrus tristeza virus of Northeastern Himalayan hills region based on 5'ORF 1a fragment (404nt) (a) and based on CP gene (672nt) (b); Lanes 1-6: Six Mirik isolates, Lane 7-9: three Rumtek isolates and Lane M:1 kb ladder and +: CTV infected Kagzilime maintained in greenhouse; -: pooled healthy samples of Kagzi lime, sweet orange and Darjeeling mandarin

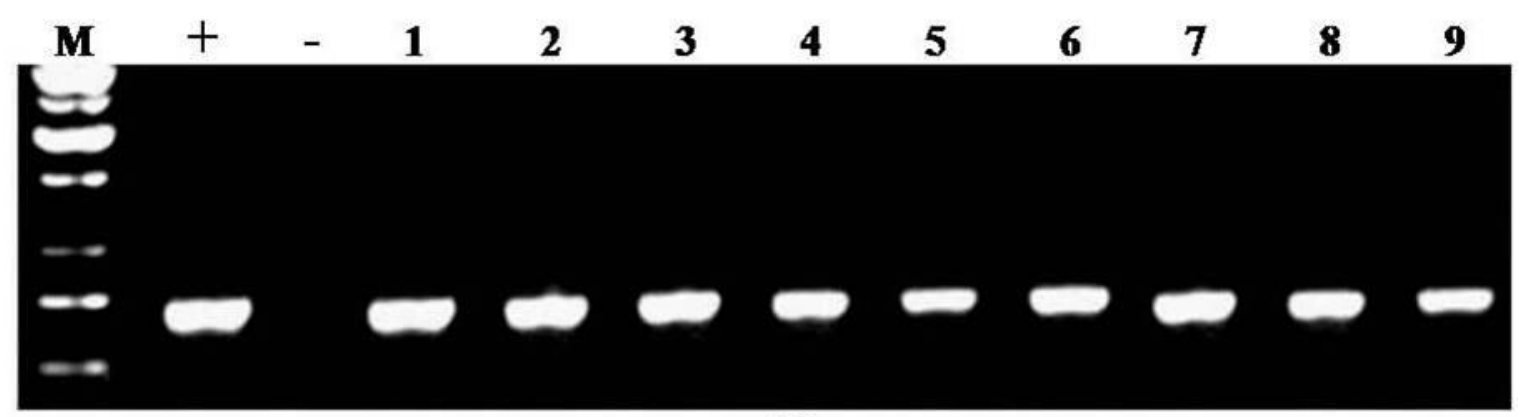

(a)

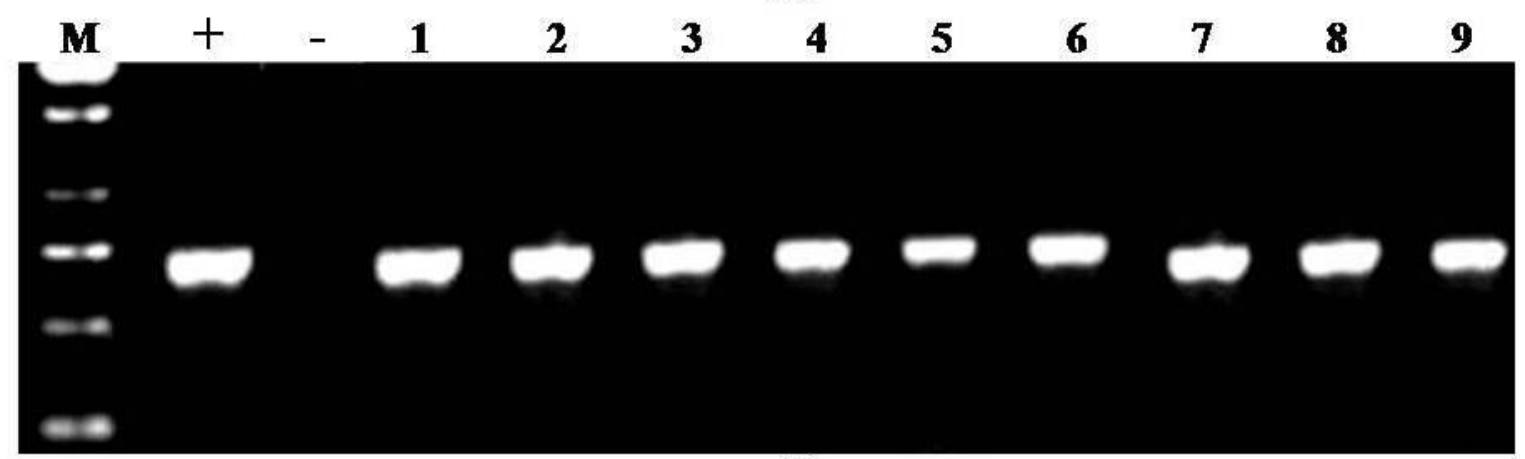

(b) 
Fig.2 Colour-coded pairwise nucleotide identity (\%) matrix of CTV isolates based on 5'ORF1a fragment (a) and CP gene (b). Each colour cell represents a percent identity score between two CTV isolates (one indicated horizontally to the left and the other vertically at the bottom). A coloured key indicates the correspondence between pairwise identities and colours displayed in the matrix

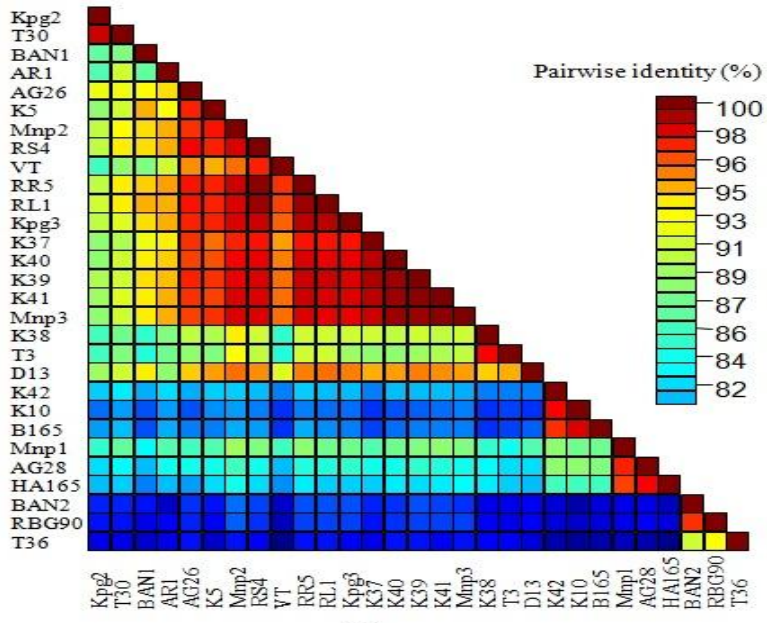

(a)

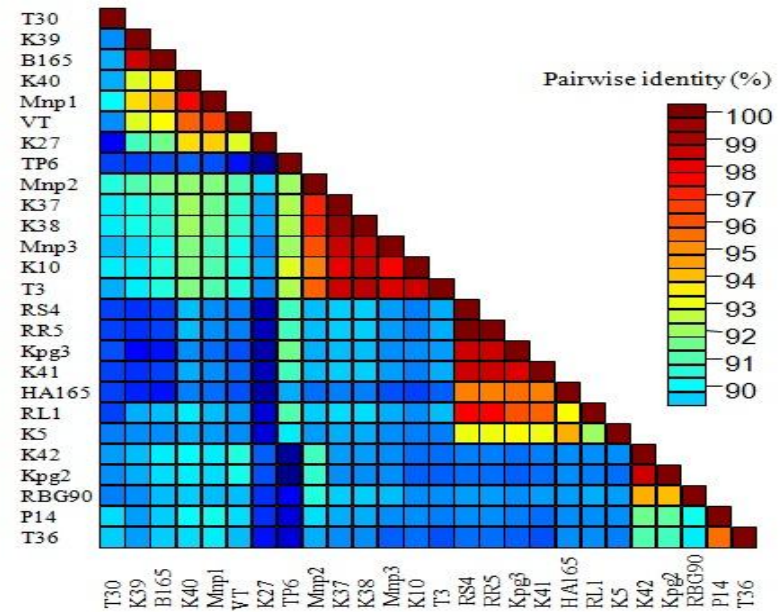

(b)

Fig.3 Phylogenetic relationships among CTV isolates using maximum likelihood parameter (1,000 bootstrap) based on 5'ORF1a fragment (a) and CP gene (b). The present isolates are highlighted and genogroups are expressed by left curly bracket or right arrow; VT, T3, T30, T36, B165, HA16-5, RB-G90 are the representative isolates of seven International recognized genotypes
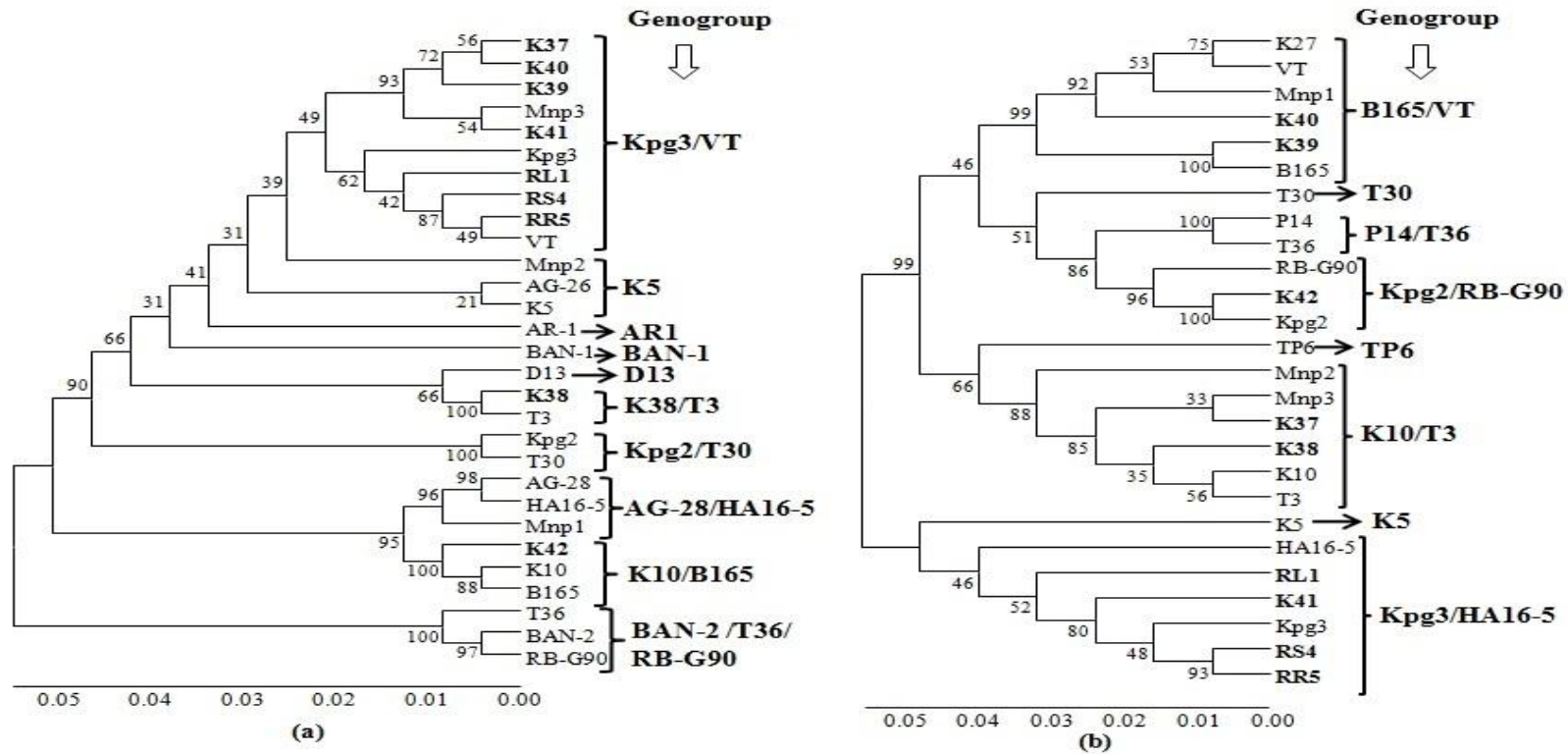

In conclusion, determination of genetic diversity, identification and distribution of CTV variants in citrus growing regions of India are essential in understanding the epidemiology and developing long term management strategy of the virus. Additionally, the sequence analysis and phylogenetic relationships of large number

of CTV isolates will lead to develop an improved diagnostics targeting group specific primers, and design molecular based management strategy through gene silencing targeting conserved sequence of the virus. Most of the mandarin orchards in the Darjeeling and Sikkim hills are three or more decade old and 
suffer from citrus declining. As the disease is horizontally spread through planting material and vertically through aphids, establishment of new orchards using disease free planting material and keeping the orchards free from aphids with regular inspection are essential to maintain the citrus industry viable and profitable. In this regard a strategy for production of CTV-free planting material for the Darjeeling hill developed earlier (Biswas et al., 2009) could be followed.

\section{Acknowledgements}

The authors are thankful to DBT, Govt. of India (Code No. 24-33) and UGC for financial support; Director, IARI; Head, Division of Plant Pathology; In-charge, ACPV, IARI, New Delhi for providing the laboratory facility, Authors are thankful to Swati Nayak for assistance in sequence data analysis.

\section{References}

Ahlawat, Y.S. 1997. Viruses, greening bacterium and viroids associated with citrus (Citrus species) decline in India. Indian J Agri Sci. 67: 51-57.

Bar-Joseph, M and Dawson, W.O. 2008. Citrus tristeza virus. Encyclopedia of Virol 1: 520-525.

Bar-Joseph, M., Marcus, R and Lee R.F. 1989. The continuous challenge of Citrus tristeza virus control. Annu Rev Phytopathol. 27: 291-316.

Biswas, K.K. 2008. Molecular diagnosis of Citrus tristeza virus in mandarin (Citrus reticulata) orchards of hills of West Bengal. Indian J Virol. 19: 26-31.

Biswas, K.K., Tarafdar, A., Jayakumar, B.K and Pun, K.B. 2009. Strategy for production of Citrus tristeza virus free mandarin (Citrus reticulata) planting material in Darjeeling hills of India. Indian Phytopath. 62: 376-80.

Biswas, K.K. 2010. Molecular characterization of Citrus tristeza virus isolates from the Northeastern Himalayan region of India. Arch Virol. 155: 959-963.
Biswas, K.K., Tarafdar, A and Sharma, S.K. 2012a. Complete genome of mandarin decline Citrus tristeza virus of Northeastern Himalayan hill region of India: comparative analyses determine recombinant. Arch Virol. 157: 579-583.

Biswas, K.K., Tarafdar, A., Diwedi, S and Lee, R.F. 2012b. Distribution, genetic diversity and recombination analysis of Citrus tristeza virus of India. Virus Genes. 45:139-148.

Biswas, K.K., Tarafdar, A., Sharma, S.K., Singh, J.K., Dwivedi, S., Biswas, K and Jayakumar, B.K. 2014. Current status of Citrus tristeza virus incidence and its spatial distribution in citrus growing geographical zones of India. Indian J Agri Sci. 84: 8-13.

Chakraborty, N.K., Ahlawat, Y.S., Varma, A., Chandra, K.J., Ramapandu, S and Kapur, S.P. 1992. Serological reactivity in Citrus tristeza virus strains in India. In Proceeding $12^{\text {th }}$ Conference of IOCV. pp: 108-112.

Clark, M.F and Bar-Joseph, M. 1984. Enzyme linked immune sorbent assay in plant virology. Methods in Virol. 7: 51-85.

Harper, S.J. 2013. Citrus tristeza virus: evolution of complex and varied genotypic groups. Front Microbiol. 4: 118.

Karasev, A,V., Boyko, V,P., Gowda, S., Nikolaeva, O.V., Hilf, M.E., Koonin, E.V., Niblett, C.L., Cline, K., Gumpf, D.J., Lee, R.F., Garnsey, S.M., Lewandowski, D.J and Dawson, W.O. 1995. Complete sequence of the Citrus tristeza virus RNA genome. Virology. 208: 511-520.

Kishore, K., Rahman, H., Kalita, H., Pandey, B and Minika, N. 2010. Prevalence of Citrus tristeza virus in mandarin of Sikkim Himalayan Region. Indian Journal of Virology. 21: 140-3.

Martin, D.P., Murrell, B., Golden, M., Khoosal, A and Muhire, B. 2015. RDP4: Detection and analysis of recombination patterns in virus genomes. Virus Evolution. 1(1): vev003. 
Martin, S., Sambade, A., Rubio, L., Vives, M.C., Moya, P., Guerri, J., Elena, S.F and Moreno, P. 2009. Contribution of recombination and selection to molecular evolution of Citrus tristeza virus. J Gen Virol. 90: 527-1538.

Melzer, M. J., Borth, W.B., Sether, D.M., Ferreira, S., Gonsalves, D and Hu, J.S. 2010. Genetic diversity and evidence for recent modular recombination in Hawaiian Citrus tristeza virus. Virus Genes. 40: 111-118.

Moreno, P., Ambros, S., Albiach-Marti, M.R., Guerri, J and Pena, L. 2008. Citrus tristeza virus: a pathogen that changed the course of the citrus industry. Mol Plant Pathol. 9: 251-268.

Muhire, B.M., Varsani, A and Martin, D.P. 2014. SDT: A Virus Classification Tool Based on Pairwise Sequence Alignment and Identity Calculation. PLOS ONE. 9(9): e108277

Palchoudhury, S., Sharma, S.K., Biswas, M.K and Biswas, K.K. 2015. Diversified Citrus tristeza virus causing decline disease in Mandarin orange in Manipur state of NEH region in India. Journal of mycology and plant pathology. 45(4), 317-323.

Roy, A and Brlansky, R.H. 2010. Genome analysis of an orange stem pitting Citrus tristeza virus isolate reveals a novel recombinant genotype. Virus Res. 151: 118-130.

Rubio, L., Ayllon, M.A., Kong, P., Fernandez, A., Polek, M., Guerri, J., Moreno, P and Falk, B.W. 2001. Genetic variation of isolates from California and Spain: evidence for mixed infections and recombination. J Virol. 75: 8054-8062.

Satyanayanana, T., Gowda, S., Mawassi, M., Albiach-Marti, M.R., Ayllon, M.A., Robertson, C., Garnsey, S.M and Dawson, W.O. 2000. Closterovirus encoded HSP70 homolog and p61 in addition to both coat proteins function inefficient virion assembly. Virology 278: 253-265.

Sharma, S.K., Tarafdar, A., Khatun, D., Kumari, S and Biswas, K.K. 2011. Intrafarm diversity and evidence of genetic recombination of Citrus tristeza virus isolates in Delhi region of India. $J P B B$. 21(1): 38-43.

Singh, J.K., Tarafdar, A., Sharma, S.K. and Biswas, K. K. 2013. Evidence of recombinant Citrus tristeza virus isolate occurring in Acid Lime cv. Pant Lemon orchard in Uttarakhand Terai region of Northern Himalaya in India. Virus Disease. 24: 35-41.

Tamura, K., Stecher, G., Peterson, D., Filipski, $A$ and Kumar, S. 2015. MEGA6: Molecular Evolutionary Genetics Analysis Version 6.0. Mol Biol Evol. 30(12): 2725-2729.

Tarafdar, A., Godara, S., Dwivedi, S., Jayakumar, B.K and Biswas, K.K. 2013. Characterization of Citrus tristeza virus and determination of genetic variability in North-east and South India. Indian Phytopath. 66(3): 302-307.

Thompson, J.D., Gibson, T.J., Plewniak, F., Jeanmougin, F and Higgins, D.G.1997. The CLUSTAL-X windowsinterface: flexible strategies for multiple sequence alignment aided by quality analysis tools. Nucleic Acid Res. 24: 4876-4882.

\section{How to cite this article:}

Palchoudhury, S., P. Ghimiray, M.K. Biswas and Biswas, K.K. 2017. Citrus tristeza Virus Variants and their Distribution in Mandarin Orchards in Northeastern Himalayan Hill Region of India. Int.J.Curr.Microbiol.App.Sci. 6(5): 1680-1690. doi: https://doi.org/10.20546/ijcmas.2017.606.196 